\title{
Ectomycorrhizal Flora Formed by Main Forest Trees in the Irtysh River Region of Central and Northeastern Kazakhstan
}

\author{
Dani Sarsekova ${ }^{1}$, Sezgin Ayan $^{2 *}$, Abzhanov Talgat $^{1}$
}

(1) S. Seifullin Kazakh Agro Technical University, Department of Forest Resources and Forestry, Nur-Sultan Zhenis Avenue 62, KZ-010011 Astana, Kazakhstan; (2) Kastamonu University, Faculty of Forestry, Silviculture Department, Kuzeykent Campus, TR-37100 Kuzeykent, Kastamonu, Turkey

* Correspondence: e-mail: sezginayan@gmail.com
Citation: Sarsekova D, Ayan S, Talgat A, 2020. Ectomycorrhizal Flora Formed by Main Forest Trees in the Irtysh River Region of Central and Northeastern Kazakhstan. South-east Eur for 11(1): 61-69. https://doi. org/10.15177/seefor.20-06.

Received: 22 Jan 2020; Revised: 28 Mar 2020, 31 Mar 2020; Accepted: 31 Mar 2020; Published online: 11 May 2020

\begin{abstract}
In this study, the aim was to determine and identify symbiotically living ectomycorrhizas of the main tree species forming forests in central and northeastern Kazakhstan. Surveys were conducted on the right bank of the Irtysh River in a mixed forest of Pinus sylvestris, Picea obovata and Betula pendula trees. The collection was formed and the primary identification of voucher samples of fruiting bodies of macromycetes collected as ectomycorrhiza forming fungi was completed. In the collection and species identification of fruiting bodies, standard methods were used. A total of 30 ectomycorrhizas belonging to Agaricomycetes were identified. The distribution of 30 species into families is as follows: Suillaceae (8), Russulaceae (7), Cortinariaceae (4), Boletaceae (3), Tricholomataceae (2), Amanitaceae (1), Cantharellaceae (1), Gomphaceae (1), Gomphidiaceae (1), Paxillaceae (1), and Bankeraceae (1). The richest genus on account of the number of species was Suillus (8). Concerning the woody host species, 17 mycorrhizas were determined to build symbiosis with $P$. sylvestris, 8 mycorrhizas with B. pendula, 6 mycorrhizas with Populus tremula, 1 mycorrhiza with $P$. obovata, 1 mycorrhiza with Quercus robur, 1 mycorrhiza with Salix sp., and 1 mycorrhiza with Pinus densiflora Siebold and Zuccarini. Ectomycorrhizas should be used as a major performance-enhancing tool in afforestation and restoration studies in the Irtysh River basin under extreme ecological conditions and under climate change effects.
\end{abstract}

Keywords: mycorrhiza; forest ecosystem; symbiotic, mycotrophy; continental climate

\section{INTRODUCTION}

The degree of mycotrophy of the main forest-forming species on Earth is one of the most important indicators of their growth and development. Over 8000 species of higher plants and 7000-10000 species of mushrooms form ectomycorrhizal relationships (Rossi et al. 2013). The most important symbiotic relationship between plants and fungi is mycorrhiza. Namely, Brundrett (2002) stated that about $80 \%$ of higher plants have mycorrhizal formations on the roots. In addition, around $83 \%$ of dicotyledons, $79 \%$ of monocotyledons and all gymnosperms have mycorrhizal life. Non-mycorrhizal plants appear on very dry or highly salty submerged areas, and habitats where soil fertility is either quite high or too low. However, mycorrhizal life has not been recorded among the members of the
Cruciferae and Chenopodiaceae families, even under all environmental conditions (Harley 1975, Brundrett 1991, Marschner 1995). According to recent studies, mycorrhization has a close functional connection with the formation of the structure, diversity, and stability of plant communities (Püschel et al. 2007, Lambers et al. 2008, Veselkin 2012a, 2012b).

This symbiotic partnership allows participating in the circulation of nutrients, optimizing plant metabolism, activating mineral nutrition, and inducing resistance to drought, salinization, heavy metals, and pathogens (Rossi et al. 2013). There is consensus that these plant-fungal associations have profound impacts on nutrient cycling and vegetation dynamics in ecosystems, particularly in temperate forests (Taylor et al. 2016, Bennett et al. 2017, Jo et al. 2018). 
The conservation of favorable living conditions in various regions of the world directly depends on the rational and careful use of forest resources. Forest ecosystems of central and northeastern Kazakhstan are one of the most important components of the Earth's biosphere. In forest biogeocenoses, the leading role belongs to ectomycorrhizal relationships (Agerer 2008, Smith and Read 2008).

It is known that for the normal development of any type of tree, specialized strains of macromycetes fungi forming ectomycorrhizal (EcM) and rhizospheric associative microorganisms are necessary (Shubin 1990, Fitter and Garbaye 1994, Brundrett 2002, Shubin 2002, Roman et al. 2005, Cairncy 2005, Wu and Xia 2006, Polenov 2013). In the case of mutualistic relations, EcM mushrooms receive from $10 \%$ to $50 \%$ of organic carbon from plants and become competitive in the soil, and thus plants have the opportunity to use the underground communication network from the mycelium of EcM mushrooms and root systems of different tree species, along which metabolites, energy sources, cofactors, vitamins, hormones, toxins and possibly genetic information are exchanged. In this case, the integration of populations and even species, communities of plants in a single giant underground communication network of the mycelium of mycorrhizal fungi occurs.

The study of ecology and physiology of EcM has been mainly concentrated in Europe, North America and Australia (Read 1999, Finlay 2005, Smith and Read 2008, Polenov 2013). The studies on the mycobiota and ectomycorrhizal macromycetes within the Republic of Kazakhstan have been carried out by Nam (1998), Abiev et al. (2000), Abiev (2015) and Veselkin et al. (2015). In addition, some pioneer studies regarding the identification and application of mycorrhizal macromycetes, particularly in Zailiysky Alatau region, were conducted by Meshkov et al. (2009a) and Meshkov (2010).

Due to the lack of the data on the mycotrophy, flora of mycorrhiza, and plant-fungi partnership in Kazakhstan forests, the aim of this research was to identify the ectomycorrhizas of the main forest-forming species in the Irtysh River region of central and northeastern Kazakhstan.

\section{MATERIALS AND METHODS}

\section{Study Area}

This study was carried out on the right bank of the Irtysh River (latitude: N 51 $57^{\circ} 56$ 92', and longitude E $78^{\circ}$ $50^{\prime} 2$ 72") of central and northeastern Kazakhstan in 2018 and 2019. Study sites include mixed forests of Scots pine and birch (Figure 1), with the presence of grassy vegetation in the protected and buffer zones (Anonymous 2009). The Irtysh River is an international river flowing through the territories of China, Kazakhstan, and Russia. Being 4,248 km long, the Irtysh River originates from the Altai Mountains in SinKiang, China, crosses the Chinese border flowing west through Zaysan Lake and northwest across eastern Kazakhstan (Huang et al. 2013). The Kazakhstan Altai covers the eastern part of the Altai range including the right subbasins of the Irtysh River. This mountainous area is covered by forests consisting of spruce, larch, pine, birch, and aspen, while Pinus sibirica Du Tour occupies the top part of the mountain slopes (Meshkov et. al. 2009b, Sarsekova et al. 2016).

Deciduous trees are located on the edge of the meadow with a predominance of small-leaved Ulmus sp. with a shut-in crown forest density of 0.7 . The species composition of plants is represented by 38 species of angiosperms and 1 species of gymnosperms belonging to 19 families. The largest number of species belongs to the family Rosaceae (4 species) and Compositae (9 species). Most of the examined species (21 species) are found in single specimens and 6 species are found very abundantly forming a dense grass cover. Both in open areas and under the canopy of trees, there is a litter layer whose thickness varies from 1-3 mm up to $7 \mathrm{~mm}$ under the trees. The moss, lichen and low shrub layer are absent within the study area (Anonymous 2009).

The climate is sharp continental and dry. This is due to the influence of dry and hot winds blowing from the Central Asian deserts in the summer. In winter, the territory of the pine forest is open to cold air flows coming from the North. The climate is characterized by cold and long winters (5.5 months), and short and hot summers with sharp temperature fluctuations in winter and summer (Anonymous 2009). The average annual air temperatures of the coldest month (January) and the warmest month (July) are $2.5^{\circ} \mathrm{C}$ and $30^{\circ} \mathrm{C}$, respectively. The average duration of the warm period is 175 days, while frost-free days' amount to 117 days. The precipitation average is 240-310 mm per year, of which $60-75 \%$ of the annual amount falls in May - September. In spring winds from the north and northeast, and in summer, south and southwest winds quickly dry out the soil. Relative humidity in the summer (at 1 p.m.) is about $40 \%$, dropping down to $10 \%$ on some days, causing intense transpiration of plants and a large loss of moisture in the soil (Anonymous 2015).

In this region, the pine forest soil is zonal. On low surfaces among tape hogs' meadow deep effervescent chernozem soils are developed, sometimes in a complex with solonets. In general, the soil profile is characterized by a slightly acidic to neutral reaction ( $\mathrm{pH}$ of aqueous extract 6.5-7.0). Soils are washed from water-soluble salts. The mechanical composition is usually light, although there are layers of heavy and medium loam (Anonymous 2009).

\section{Sampling and Identification of Macromycetes}

The materials of macromycetes were collected in the central and northeastern part of Kazakhstan. Two methods of sampling were applied, including route and stationary research method. The routes covered various forest biocenoses - in pure or mixed forests of $P$. sylvestris $L$. with $B$. pendula Roth. Seven permanent multiyear transects with a total area of $1080 \mathrm{~m}^{2}$ were marked where the sampling of macromycetes was performed every 10-15 days during the seasons of 2018 and 2019. The collection was formed from the sampled material, and primary identification of voucher samples of fruiting bodies of macromycetes was performed. All the collected macromycetes were sampled as ectomycorrhizal fungi under $P$. sylvestris L., $P$. obovata Ledeb. and B. pendula Roth trees. 

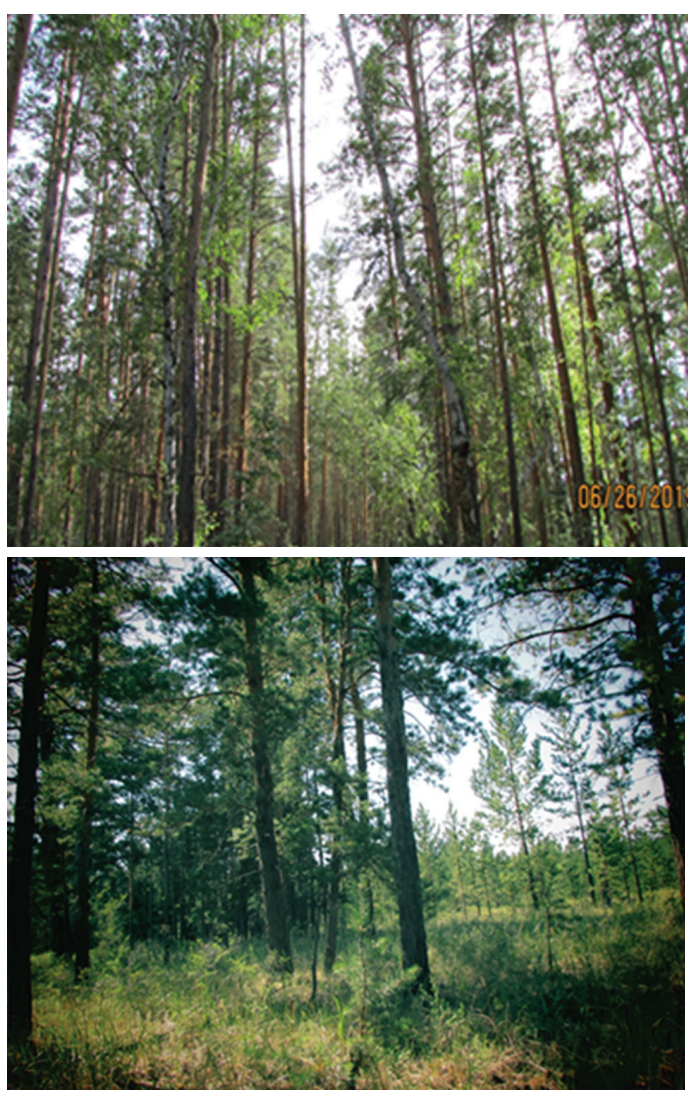

Figure 1. Pure Scots pine (upper image), and birch and Scots pine mixed forest (lower image) where samples were collected.

During the identification of fruiting bodies, standard methods were applied, using the available identifiers such as the resource www.indexfungorum, as well as the web-sites on "Mushrooms of the Kaluga Region" and "Mushrooms of the Novosibirsk Region". Micromorphological studies of characters were performed under the light microscope (Altami SM0745-T, St. Petersburg, Russia), at 400x$1000 \times$ magnification. To identify the natural color of the microstructures, the preparations were viewed in distilled water and in a 3-5\% $\mathrm{KOH}$ solution. Hyaline structures were stained with a $5 \%$ aqueous solution of safranin, while the presence or absence of amyloid and dextrinoid structures was determined using Meltzer's reagent. To determine the type of fungal symbiont in the ectomycorrhiza, the morphotyping method was used according to Agerer (2008). For these purposes, soil blocks $(10 \times 10 \times 20 \mathrm{~cm}$ in size) were taken within the projection of the crown of mature trees, according to the method of concentric sampling (Smith and Smith 2011). Before sampling, the upper undecomposed layer of the litter was removed. Coniferous seedlings were extracted from the soil with the most intact root system. Moreover, DNA was isolated from the specimens that could not be identified using the conventional identification tools.

The samples were wrapped in the aluminum foil and stored at a temperature of $4^{\circ} \mathrm{C}$. The roots were washed under the running water, cut into 3 to $5 \mathrm{~cm}$ segments, and ectomycorrhizal endings were separated under a magnifying glass with tweezers and scissors. Morphotyping of ectomycorrhiza was performed using a stereomicroscope in the binocular and trinocular version (Altami SMO745-T), equipped with an Altami UCMOSO3100KPA video camera. Based on the nature of branching, the color of the ectomycorrhizal ends, features of the mantle surface, the presence or absence of external mycelium and rhizomorph, and morphotyping were performed according to the DEEMY system (Agerer 2008). The data were entered into a specially developed checklist. The selected ectomycorrhizas were photographed and fixed in $70 \%$ ethanol for DNA isolation (Gardes and Bruns 1993). In determining the species affiliation of voucher samples of fruiting bodies, consultations were made by personal communication with leading mycologists from Russia, Sweden, and Norway during the XV International Meeting on Macromycetes held in August 2018 in Tomsk.

\section{In Vitro Culture and Cultivation}

For the mycelial development, Khudyakov-Voznyakovskaya, Hagem, and Wort-agar media optimized for the $\mathrm{C} / \mathrm{N}$ ratio and thiamine was used (Kõljalg et al. 2013). Aseptic conditions were maintained during the superficial and deep cultivation of mycelium (Bukhalo 1988). At the same time, optimal cultivation modes have been optimized and used. In total, 25 strains were developed into in vitro cultures.

\section{RESULTS}

A total of 30 ectomycorrhizas belonging to Agaricomycetes were identified (Table 1). The distribution of 30 species into families was as follows; Suillaceae (8), Russulaceae (7), Cortinariaceae (4), Boletaceae (3), Tricholomataceae (2), Amanitaceae (1), Cantharellaceae (1), Gomphaceae (1), Gomphidiaceae (1), Paxillaceae (1), and Bankeraceae (1). The genus with the highest number of recorded species was Suillus (8) (Figure 2). The photos of some fungi identified in the research are shown in Figure 3.

In the study area, three of the sampled tree species were coniferous and four were broadleaved. In total, $63.3 \%$ of all recorded mycorrhizae have established a symbiotic life with a coniferous host species (Table 2). Following the sampling and identification, 17 ectomycorrhizas were recorded under $P$. sylvestris, 8 under $B$. pendula, 6 under $P$. tremula, 1 under $P$. obovata, 1 under $Q$. robur, 1 under Salix sp., and 1 under $P$. densiflora. It should be noted that some species such as Paxillus involutus, Russula undulata, Cortinarius sp. and Cantharellus cibarius formed a symbiotic relationship with both coniferous and broadleaved tree species (Table 2, Figure 4). 
Table 1. The list of recorded ectomycorrhizas in the Irtysh River region.

\begin{tabular}{|c|c|c|c|}
\hline № & Scientific name & Class & Family \\
\hline 1 & Amanita muscaria (L.) Lam. 1783 & \multirow{30}{*}{ 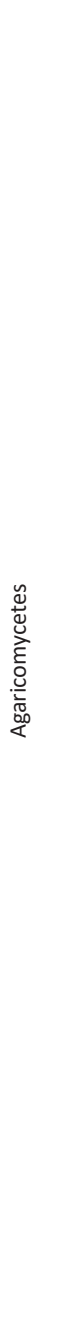 } & Amanitaceae \\
\hline 2 & Boletus satanas Lenz, 1831 & & Boletaceae \\
\hline 3 & Cantharellus cibarius Fr. 1821 & & Cantharellaceae \\
\hline 4 & Chroogomphus rutilus (Schaeff.) OK Mill. 1964 & & Gomphidiaceae \\
\hline 5 & Cortinarius nemorensis (Fr.) JE Lange 1940 & & Cortinariaceae \\
\hline 6 & Cortinarius sp. & & Cortinariaceae \\
\hline 7 & Cortinarius sp. (Bull.) J. Kickxf. 1867 & & Cortinariaceae \\
\hline 8 & Cortinarius sp. sensu NCL (1960) & & Cortinariaceae \\
\hline 9 & Hydnellum ferrugineum (Fr.) P. Karst. 1879 & & Bankeraceae \\
\hline 10 & Lactarius controversus Pers. 1800 & & Russulaceae \\
\hline 11 & Lactarius deliciosus (L.) Grey 1821s & & Russulaceae \\
\hline 12 & Lactarius torminosus (Schaeff.) Grey 1821 & & Russulaceae \\
\hline 13 & Lactifluus flexuosus (PERS.) KUNTZE 1891 & & Russulaceae \\
\hline 14 & Leccinum aurantiacum (Bull.) Grey 1821 & & Boletaceae \\
\hline 15 & Leccinum scabrum (Bull.) Grey 1821 & & Boletaceae \\
\hline 16 & Paxillus involutus (Batsch) Fr., 1838 & & Paxillaceae \\
\hline 17 & Ramaria stricta (Pers.) Quél. 1888 & & Gomphaceae \\
\hline 18 & Russula grisea Fr. 1838 & & Russulaceae \\
\hline 19 & Russula undulata Velen. 1920 & & Russulaceae \\
\hline 20 & Russula vesca Fr. 1836 & & Russulaceae \\
\hline 21 & Suillus bovinus (L.) Roussel 1796 & & Suillaceae \\
\hline 22 & Suillus granulatus (L.) Roussel 1796 & & Suillaceae \\
\hline 23 & Suillus luteus (L.) Roussel 1796 & & Suillaceae \\
\hline 24 & Suillus placidus (Bonord.) Singer 1945 & & Suillaceae \\
\hline 25 & Suillus salmonicolor (Frost) Halling 1983 & & Suillaceae \\
\hline 26 & Suillus sibiricus (Singer) Singer 1945 & & Suillaceae \\
\hline 27 & Suillus tridentinus (Bres.) Singer 1945 & & Suillaceae \\
\hline 28 & Suillus variegatus (Sw.) Richon \& Roze 1888 & & Suillacaee \\
\hline 29 & Tricholoma sp. & & Tricholomataceae \\
\hline 30 & Tricholomae questre (L.) P. Kumm. 1871 & & Tricholomataceae \\
\hline
\end{tabular}

10

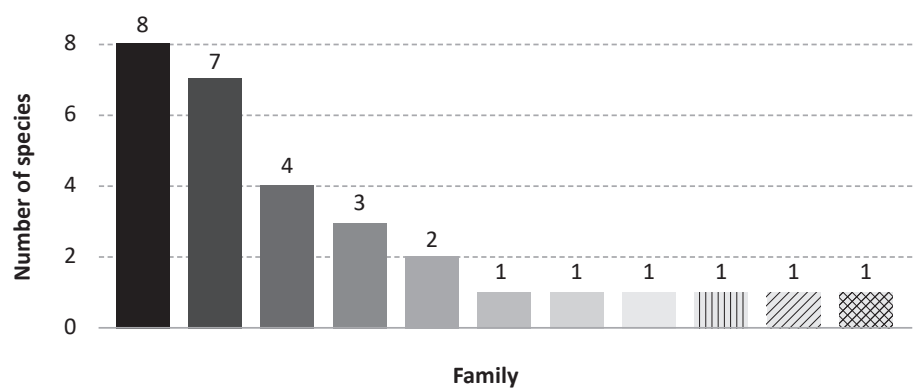

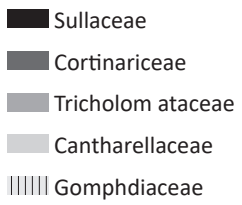

xym Bankeraceae

Figure 2. The number of ectomycorrhiza by families. 

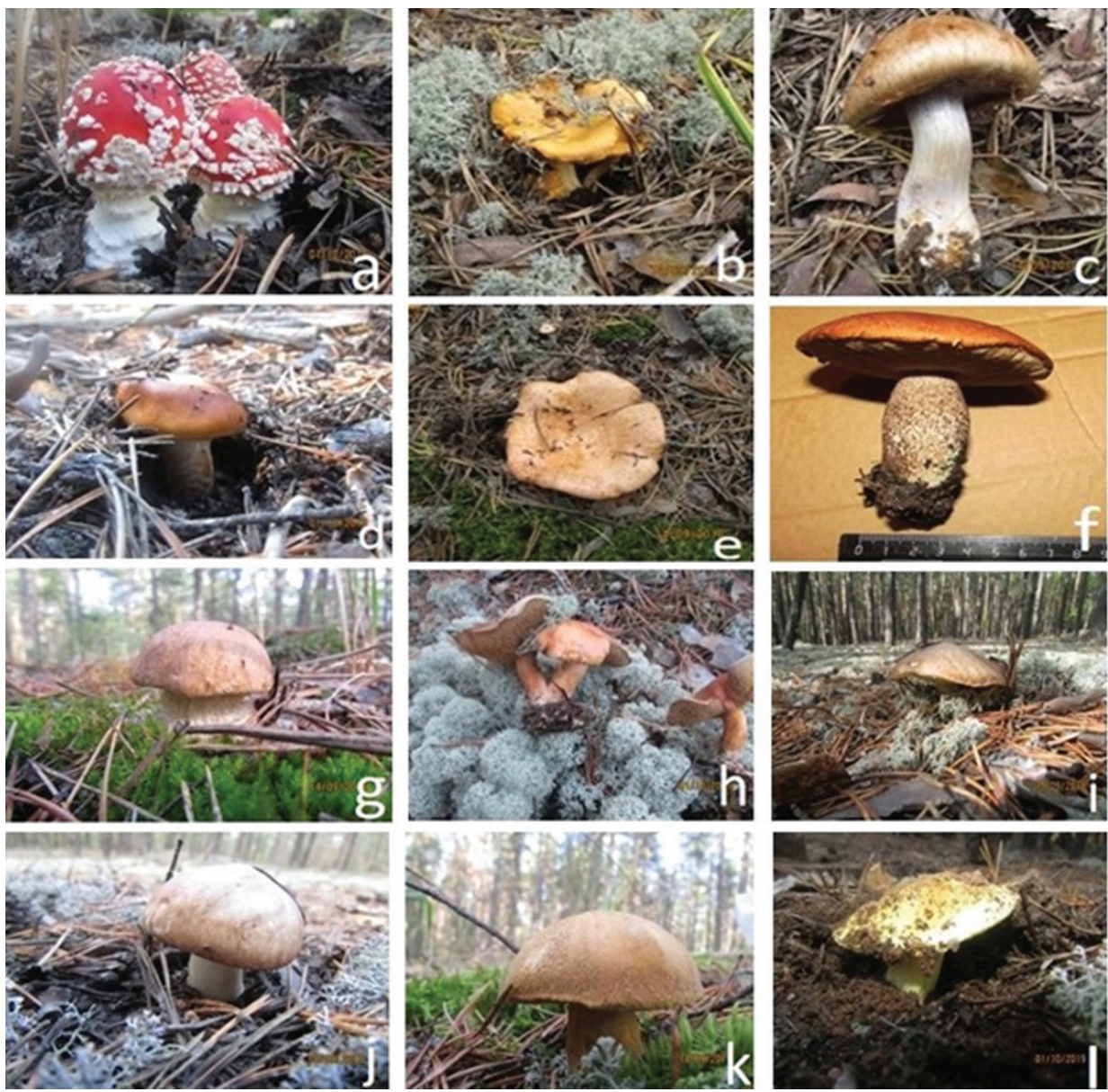

Figure 3. Representative photos of the macromycetes identified in this study: (a) Amanita muscaria; (b) Cantharellus cibarius; (c) Cortinarius nemorensis; (d) C. mucosus; (e) Lactarius delicious; (f) Leccinium aurantiacum; (g) L. scabrum; (h) Suillus bovinus; (i) S. luteus; (j) S. sibiricus; (k) S. variegatus; (I) Tricholoma equestre.
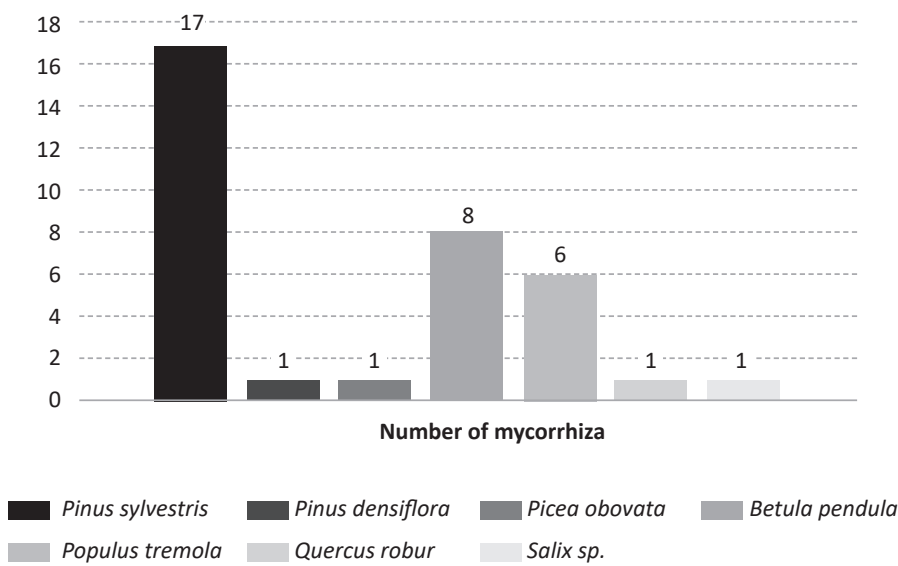

Figure 4. The number of ectomycorrhiza by tree species. 
Table 2. Host trees and status of the detected and diagnosed mycorrhizas.

\begin{tabular}{|c|c|c|c|}
\hline Latin name of the macromycetes & Common name & Mycorrhizal status & Latin name of host tree \\
\hline Amanita muscaria & Fly agaric (Fly amanita) & Mycorrhiza & Pinus sylvestris $\mathrm{L}$. \\
\hline Boletus satanas & Satan's bolete (Devil's bolete) & Not mycorrhiza & - \\
\hline Cantharellus cibarius & Chanterelle & Mycorrhiza & $\begin{array}{l}\text { Pinus sylvestris L., } \\
\text { Betula pendula Roth., } \\
\text { Picea obovata Ledeb. }\end{array}$ \\
\hline Chroogomphus rutilus & Brown slimecap (Copper spike) & Mycorrhiza & Pinus sylvestris L. \\
\hline Cortinarius nemorensis & Contrary webcap & Mycorrhiza & Quercus robur $\mathrm{L}$. \\
\hline Cortinarius sp. & Orange webcap (Slimy cortinarius) & Mycorrhiza & Pinus sylvestris L. \\
\hline Cortinarius sp. sensu & Cortinar (webcap) & Mycorrhiza & $\begin{array}{l}\text { Pinus sylvestris } \mathrm{L} \text {. } \\
\text { Betula pendula Roth. }\end{array}$ \\
\hline Hydnellum ferrugineum & $\begin{array}{l}\text { Mealy tooth (Reddish-brown corky } \\
\text { spine) }\end{array}$ & Not mycorrhiza & - \\
\hline Lactarius controversus & Blushing milk cap & Mycorrhiza & $\begin{array}{l}\text { Salix } \mathrm{L} . \\
\text { Populus tremula } \mathrm{L} \text {. }\end{array}$ \\
\hline Lactarius deliciosus & Saffron milk cap & Mycorrhiza & Pinus sy/vestris L. \\
\hline Lactarius torminosus & Bearded milk cap & Mycorrhiza & Betula pendula Roth. \\
\hline Lactifluus flexuosus & Stumpy milk cap & Mycorrhiza & Populus tremula $\mathrm{L}$ \\
\hline Leccinum aurantiacum & Orange oak bolete & Mycorrhiza & Populus tremula L. \\
\hline Leccinum scabrum & Brown birch bolete & Mycorrhiza & Betula pendula Roth. \\
\hline Paxillus involutus & $\begin{array}{l}\text { Brown roll-rim } \\
\text { (common roll-rim, poisonpax) }\end{array}$ & Mycorrhiza & $\begin{array}{l}\text { Betula pendula Roth., } \\
\text { Populus tremula L., } \\
\text { Pinus sylvestris L. }\end{array}$ \\
\hline Ramaria stricta & Strict-branch coral & Not mycorrhiza & - \\
\hline Russula grisea & Milk-white brittlegill & Mycorrhiza & - \\
\hline Russula undulata & Brittlegill & Mycorrhiza & $\begin{array}{l}\text { Betula pendula Roth., } \\
\text { Pinus sylvestris } \mathrm{L} \text {. }\end{array}$ \\
\hline Russula vesca & Bare-toothed russula (flirt) & Mycorrhiza & Betula pendula Roth. \\
\hline Suillus bovinus & Bovine bolete & Mycorrhiza & Pinus sylvestris $\mathrm{L}$. \\
\hline Suillus granulatus & Weeping bolete & Mycorrhiza & $\begin{array}{l}\text { Pinus sylvestris } \mathrm{L} \text {. } \\
\text { P. densiflora Siebold et Zucc. }\end{array}$ \\
\hline Suillus luteus & Slippery Jack & Mycorrhiza & Pinus sylvestris $\mathrm{L}$. \\
\hline Suillus placidus & Slippery white bolete & Mycorrhiza & Pinus sylvestris L. \\
\hline Suillus salmonicolor & Slippery jill & Mycorrhiza & Pinus sylvestris L. \\
\hline Suillus sibiricus & Siberian slippery jack & Mycorrhiza & Pinus sylvestris L. \\
\hline Suillus tridentinus & Orange larch bolete & Mycorrhiza & Pinus sylvestris L. \\
\hline Suillus variegatus & Velvet bolete & Mycorrhiza & Pinus sylvestris L. \\
\hline Tricholoma equestre & Man on horseback (Yellow knight) & Mycorrhiza & Populus tremula $\mathrm{L}$. \\
\hline Tricholoma sp. & $\begin{array}{l}\text { Grey knight } \\
\text { (Dirty tricholoma) }\end{array}$ & Mycorrhiza & $\begin{array}{l}\text { Betula pendula Roth., } \\
\text { Populus tremula L. }\end{array}$ \\
\hline
\end{tabular}

\section{DISCUSSION}

A rich diversity of 30 different mycorrhiza species was recorded in this study. Of these 30 mycorrhizae, 17 were determined under $P$. sylvestris, 8 under $B$. pendula, 6 under $P$. tremula, 1 under $P$. obovata, 1 under $Q$. robur, 1 under Salix sp., and 1 under $P$. densiflora. As determined within the scope of research, all Suillus species, Amanita muscaria and Chroogomphus rutilus associated a partnership with conifers, while the species of Leccinum, Tricholoma and Lactifluus flexuosus formed a partnership with hardwoods. In addition, Cantharellus cibarius, Paxillus involutus, the species of Cortinarius and Lactarius presented a partnership with both conifers and hardwoods on a broad spectrum. 
Some macromycetes are selective in forming a partnership, while others may form a partnership in a very large spectrum. For example, of the genus Laccaria, Suillus form ectomycorrhiza on coniferous seedlings (early-stage fungi), fungi from the genera Russula, Boletus mycorrhizal roots of older conifers (late-stage fungi). For example, Amanita muscaria and Boletus edulis can form mycorrhiza with trees that are systematically distant from each other, such as conifers and hardwoods. There is a definite connection between the systematic groups of fungi and plants. Thus, fungi of the genus Gomphidius form mycorrhiza mainly with coniferous trees, while in Suillus sibiricus, mycoses with Pinus sibirica are more fixed than with Pinus sylvestris. Leccinum chromapes is confined to black birch (Betula dahurica Pall.) and does not form mycorrhiza with white birch (Betula pubescens Ehrh.) On the contrary, representatives of the genera Cortinarius, Inocybe, as well as Laccaria laccata, Paxiluus involutus, Amanita vaginata, and Hebeloma crustuliniforme possess a wide valence in relation to tree species (Singer 1938).

Valuable coniferous forests of the Irtysh River regions and Kazakhstan Altai have been exhausted by timber cutting and fires. The continuous felling of forests in the river basins of Bukhtarma and Uba in the East Kazakhstan region is responsible for the considerable loss of water in the Irtysh River. Because of the increasing demand for energy firewood, harvesting of these important forests has considerably increased (Meshkov et al. 2009b). Most ectomycorrhizal fungi cannot remain viable for a long time unless they find a host plant and establish mutually beneficial contact (Shemakhanova 1962, Shubin 1990, Timonen and Marschner 2005). The biodiversity of the fungi forming ectomycorrhiza with woody plants decreases rapidly due to clear-cutting operations and fires. The restoration of the natural diversity of this important component of forest biogeocenosis requires a long period of time if human-made and natural disturbances are severe in these forest areas. A number of researchers have shown that direct and indirect anthropogenic effects can very negatively affect the development of ectomycorrhizal mushrooms (Massicotte et al. 1998). The findings of this study are very important in this respect, in the sense of easier restoration of afforested areas.

Meshkov et al. (2009b) have emphasized that the priority should be given to forest rehabilitation on burned areas and lands where the forest was previously removed, including in the ribbon-like relict pine forests of the Irtysh region of the Kazakh Uplands (Akmola and Karaganda Provinces), plain förests of Kostanay Province. In addition, Meshkov et al (2009b) and Sarsekova et al. (2016) recommended that in many parts of Kazakhstan, in the degraded forest areas, mycorrhizas should be used as a major improvement tool.

Applied aspects of the application of mycorrhization were investigated by Meshkov who was the first in Kazakhstan not only to define four species of macromycetes into the culture, but also to develop a technology for their scaling and application in the form of mycorrhized compost for reforestation in Zailiysky Alatau
(Meshkov et al. 2009a, Meshkov 2010). Such practical projects should be increased and implemented as soon as possible. In this study, due to higher atmospheric and soil drought during the autumn-summer period in 2018 and 2019, no mass fruits of fungi were formed at the end of September. Following the rains in late September, the fruit-bearing macromycetes' organs started to appear. Moreover, most of the recorded mycorrhizae (63.3\%) were found under the coniferous host species (Table 2). However, this could be associated with the dominance of coniferous tree species in the studied region, and the most sampled hosts in this study belonged to conifers. Vaishlya et al. (2017) emphasized that coniferous trees are able to form symbiotic relationship with 200-300 species of ectomycorrhizal fungi. There are nearly 50 ectomycorrhizal fungi species which are capable of forming ectomycorrhizas with Pinus sibirica in Tomsk region of west Siberia.

Species of Suillus are found all over the northern hemisphere where members of the Pinaceae tree family can be found. Although a few species are distributed in mainly mountainous regions of tropical regions, most are limited to temperate areas (Singer 1986). The Russulaceae have a worldwide distribution, but there are differences among the distribution of genera. Russula is the most widespread, found in North, Central and South America (Buyck and Ovrebo 2002), Europe, temperate (Gorbunova 2014) and tropical Asia, Africa (Natarajan et al. 2005), and Australasia (McNabb 1973). It is the only Russulaceae genus that occurs in the Nothofagus zone of temperate South America (Singer 1953). Lactarius is mainly known from the north temperate zone, but some species also occur in tropical Asia and Africa. Lactifluus has a more tropical distribution than Lactarius, with most species known from tropical Africa, Asia, South America, and Australasia, but some also occurring in the north temperate zone (Verbeken and Nuytinck 2013).

In addition, Shi et al. (2016) stated that there are still critical gaps remaining in our understanding of biogeographic patterns of mycorrhizal associations, and our limited knowledge of the anthropogenic factors responsible for shifting plant-mycorrhizal distributions has hindered the efforts to predict the ecosystem feedbacks to climate change.

\section{CONCLUSION}

The species of ectomycorrhizae identified in the study and the knowledge about which tree species they form partnership with have great critical importance, especially for the propagation of ectomycorrhizal seedlings to be grown in the central and northeastern Kazakhstan regions where environmental conditions and anthropogenic effects are severe. As a result, ectomycorrhizas must be used as a major performance-enhancing tool in afforestation and restoration studies in the Irtysh River basin, under extreme ecological conditions and climate change effects. 


\section{Author Contributions}

DS, SA, and AT conceived and designed the research; DS and AT carried out the field measurements; AT performed laboratory analysis; DS secured the research funding; DS and SA supervised the research and SA wrote the manuscript.

\section{Funding}

The project has been financed by the Ministry of Agriculture of the Republic of Kazakhstan.

\section{Acknowledgments}

The authors would like to thank to Assoc. Prof. Dr. Serhat Ursavas, Çankırı Karatekin University, Faculty of Forestry, in Çankırı, Turkey and Dr. Mertcan Karadeniz, Kastamonu University, Faculty of Forestry, in Kastamonu, Turkey, for their valuable contributions to the paper.

\section{Conflicts of Interest}

The authors declare no conflict of interest.

\section{REFERENCES}

Abiev S, Abdildina DI, Feoktistov A, 2000. Collection of cultures of basidiomycetes of the Institute of Botany and Phytointroduction. Proceedings of the International Conference "Mycology and Cryptogamous Botany in Russia". - SPb., pp. 47. (in Russian).

Abiev SA, 2015. Edible fungi of the order Agaricales of specially protected natural territories of central and north-eastern Kazakhstan: the creation of a collection of strains and their molecular identification. In: Abiev SA, Shnyreva AV, Nam GA, Asilkhanova RZ, Abisheva G (eds) News of Nat. Academy of Sciences of the Republic of Kazakhstan, 309: 154-161 (in Russian).

Agerer R, 2008. Colour Atlas of Ectomycorrhizae. Einhorn-Verlag, Schwäbisch-Gmünd. 1996-2008. V. I-VI.

Anonymous, 2009. Management Plan of the State Forest Natural Reserve "ErtisOrmany", Shalday. (in Russian).

Anonymous, 2015. Information on the scientific and research work of the Department of Information Science and Monitoring of the GLPR “Ertis Ormany”. (in Russian).

Bennett JA, Maherali H, Reinhart KO, Lekberg Y, Hart MM, Klironomos J, 2017. Plant-soil feedbacks and mycorrhizal type influence temperate forest population dynamics. Science 355(6321): 181-184. https://doi.org/10.1126/science.aai8212.

Brundrett M, 1991. Mycorrhizas in Naturel Ecosystem. Adv Ecol Res 21: 171-313. https://doi.org/10.1016/S0065-2504(08)60099-9.

Brundrett MC, 2002. Coevolution of roots and mycorrhizas of land plants. New Phytol 154(2): 275-304. https://doi.org/10.1046/ j.1469-8137.2002.00397.x.

Bukhalo AS, 1988. Higher edible basidiomycetes in pure culture. Science Dumka, Kiev, 144 p.

Buyck B, Ovrebo CL, 2002. New and interesting Russula species from Panama. Mycologia 94(5): 888-901. https://doi.org/10.10 80/15572536.2003.11833183.

Cairncy JWG, 2005. Basidiomycete mycelia in forest soils: dimensions, dynamics and roles in nutrient distribution. Mycol Res 109(1): 7-20. https://doi.org/10.1017/S0953756204001753.

Finlay RD, 2005. Mycorrhizal symbiosis: myths, misconceptions, new perspectives and future research priorities. Mycologist 19(3): 90-95. https://doi.org/10.1017/S0269915X05003010.

Fitter AM, Garbaye J, 1994. Interactions between mycorrhizal fungi and other soil organisms. Plant Soil 159(1): 123-132. https://doi. org/10.1007/BF00000101.

Gardes M, Bruns TD, 1993. ITS primers with enhanced specificity for basidiomycetes - application to the identification of mycorrhizae and rusts. Mol Ecol 2(2): 113-118. https://doi.org/10.1111/ j.1365-294X.1993.tb00005.x.

Gorbunova IA, 2014. Biota of agaricoid and gasteriod basidiomycetes of dryad tundras of the Altai-Sayan mountain area (Southern Siberia). Contemp Probl Ecol 7(1): 39-44. https:// doi.org/10.1134/S1995425514010065.

Harley JL, 1975. The Mycorhizal Associations. Encylopedia of Plant Physiology 17: 148-186.
Huang F, Xia Z, Guo Z, Yang F, 2013. Climate change detection and annual extreme temperature analysis of the Irtysh Basin. Theor Appl Climatol 111: 465-470. https://doi.org/10.1007/s00704012-0676-0.

Jo I, Potter KM, Domke GM, Fei S, 2018. Dominant forest tree mycorrhizal type mediates understory plant invasions. Ecol Lett 21(2): 217-224. https://doi.org/10.1111/ele.12884.

Kõljalg U, Nilsson RH, Abarenkov K, 2013. Towards a unified paradigm for sequence-based identification of fungi. Mol Ecol 22(21): 5271-5277. https://doi.org/10.1111/mec.12481.

Lambers H, Raven JA, Shaver GR, Smith SE, 2008. Plant nutrient acquisition strategies change with soil age. Trends Ecol Evol 23(2): 95-103. https://doi.org/10.1016/i.tree.2007.10.008.

Marschner H, 1995. Mycorrhizas. Mineral Nutrition of Higher Plants. $2^{\text {nd }}$ edn. Academic Press, London, United Kingdom, 625 p. https://doi.org/10.1016/C2009-0-63043-9.

Massicotte HB, Melville LH, Peterson RL, Luoma DL, 1998. Anatomical aspects of field ectomyconliizas on Polygonum viviparum (Polygonaceae) arid Kobresia bellardii (Cypcraceae). Mycorrhiza 7: 287-292. https://doi.org/10.1007/s005720050194.

McNabb RF, 1973. Russulaceae of New Zealand 2. Russula Pers. ex S. F. Gray. New Zeal J Bot 11(4): 673-730. https://doi.org/10.108 $\underline{0 / 0028825 X .1973 .10430308 .}$

Meshkov VV, Nam GA, Rakhimova EV, 2009a. Use of mycorrhizal fungi for reforestation and afforestation in Zailiysky Alatau. In: Proceedings of the International Conference "Problems of Forest Phytopathology and Mycology". Perm, Russia. (in Russian).

Meshkov VV, Sabit BB, Anastasia VY, Almazbek O, 2009b. Forest Rehabilitation in Kazakhstan, In: Lee DK, Kleine M (eds) Keep Asia Green, Volume IV, "West and Central Asia", IUFRO Headquarters, Vienna, Austria, 2009, pp. 83-129. https://www.iufro.org/ science/special/spdc/actpro/\%20keep/ws20-iv/.

Meshkov VV, 2010. Justification and technology for the production of mycorrhized compost for forest growing and mushrooms for commercial purposes (for example, the ribbon burs of Irtysh). Abstract, Almaty, pp. 24 (in Russian).

Nam GA, 1998. To the mycobiota of hat mushrooms of the Dzungarian Alatau. Search Ser Natures Sciences 1: 35-41. (in Russian).

Natarajan KN, Senthilarasu G, Kumaresan V, Rivière T, 2005. Diversity in ectomycorrhizal fungi of a dipterocarp forest in Western Ghats. Current Science 88(12): 1893-1895.

Polenov AB, 2013. Mushrooms. Edible and inedible: The most complete and modern atlas-determinant. LLC Polygon Publishing House, 160 p. (in Russian).

Püschel D, Rydlova J, Vosatka M, 2007. Mycorrhiza influences plant community structure in succession on spoil banks. Basic Appl Ecol 8(6): 510-520. https://doi.org/10.1016/i.baae.2006.09.002. 
Read DJ, 1999. Plant-microbe mutualisms and community structure. In: Schulze ED, Mooney HA (eds) Biodiversity and ecosystem function. Springer, Berlin, Heidelberg, Germany, pp. 181-209. https://doi.org/10.1007/978-3-642-58001-7 9.

Roman M, Claveria V, Miguel M, 2005. A revision of the descriptions of ectomycorrhizas published since 1961. Mycology Research 109 (10): 1063-1104. https://doi.org/10.1017/S0953756205003564.

Rossietal MS, 2013. Effect of aqueous extracts of garlic (Allium sativum) on the morphology and infectivity of a Venezuelan isolate of Trypanosom aevansi. Acta Microsc 22(1): 69-78.

Sarsekova D, Ayan S, Kitaibekova S, 2016. Review of desertification and forest degradation issue in Kazakhstan. International Scientific Journal 47(1): 39-45.

Shemakhanova NM, 1962. Mycotrophy of wood species. Publishing House of the Academy of Sciences of the USSR, 374 p. (in Russian).

Shi M, Fisher JB, Brzostek ER, Phillips RP, 2016. Carbon cost of plant nitrogen acquisition: Global carbon cycle impact from an improved plant nitrogen cycle in the Community Land Model. Glob Chang Biol 22(3): 1299-1314. https://doi.org/10.1111/ gcb.13131.

Shubin VI, 1990. Macromycetes-symbiotrophs of forest phytocenoses of the taiga zone and their use. 97 p. (in Russian).

Shubin VI, 2002. About bio- and saprotrophy of mycorrhizal fungi of woody plants. I Congress of Mycologists of Russia. PhD Thesis, 206 p. (in Russian).

Singer R, 1938. Sur les genres Ixocomus, Boletinus, Phylloporus, Gyrodon et Gomphidius. Revue de Mycologie 3 (4-5): 35-53. (in French).

Singer R, 1953. Four years of mycological work in southern South America. Mycologia 45(6): 865-891. https://doi.org/10.1080/00 275514.1953.12024322.

Singer R, 1986. The Agaricales in Modern Taxonomy. $4^{\text {th }}$ edn. Koeltz Scientific Books, Koenigstein, Germany, pp. 752-757.

Smith SE, Read DJ, 2008. Mycorrhizal symbiosis. $3^{\text {rd }}$ edn. Academic Press, London, United Kingdom, 800 p. https://doi.org/10.1016/ B978-0-12-370526-6.X5001-6.
Smith SE, Smith FA, 2011. Roles of arbuscular mycorrhizas in plant nutrition and growth: New paradigms from cellular to ecosystem scales. Annu Rev Plant Biol 62: 227-250. https://doi.org/10.1146/ annurev-arplant-042110-103846.

Taylor MK, Lankau RA, Wurzburger N, 2016. Mycorrhizal associations of trees have different indirect effects on organic matter decomposition. J Ecol 104(6): 1576-1584. https://doi. org/10.1111/1365-2745.12629.

Timonen S, Marschner P, 2005. Mycorrhizosphere concept. Mukerji KG, Manoharachary C, Singh J (eds) Microbial activity in the rhizosphere. Springer Verlag, Berlin, Heidelberg, Germany, pp. 155-172. https://doi.org/10.1007/3-540-29420-1 9.

Vaishlya OB, Kudashova NN, Gashkov SI, Korbysheva KS, Bakhtinskaya IA, 2017. First list of macromycetes forming ectomycorrhizas in cedar and pine forests of Tomsk region of west Siberia. Int J Env Stud 74(5): 752-770. https://doi.org/10.10 80/00207233.2017.1294422.

Verbeken A, Nuytinck J, 2013. Not every milkcap is a Lactarius. Scripta Botanica Belgica 51: 162-168.

Veselkin DV, 2012a. Stabilization of the ratio between the numbers of species of different mycorrhizal status: An attractor of progressive succession. Izv Samarsk Nauch Tsentra Ross Akad Nauk 14(1)5: 1206-1209.

Veselkin DV, 2012b. Participation of plants of different mycotrophic status in the succession leading to "agrosteppe" formation. Russ J Ecol 43(4): 289-293. https://doi.org/10.1134/ S1067413612030174.

Veselkin DV, Kupriynanov AN, Manakov JA, Betekhtina AA, Prasad MNV, 2015. Mycorrhizal plants' accelerated revegetation on coal mine overburden in the dry steppes of Kazakhstan. In: Thangavel P, Sridevi G (eds) Environmental Sustainability. Springer, New Delhi, India, pp. 265-282. https://doi.org/10.1007/978-81-3222056-5 16

Wu QS, Xia RX, 2006. Arbuscular mycorrhizal funga influence growth, osmotic, adjustment and photosynthesis of citrus under well-water and water stress conditions. J Plant Physiol 163(4): 417-425. https://doi.org/10.1016/i.jplph.2005.04.024. 